\title{
Assessing Cost Efficiency among Small Scale Rice Producers in the West Region of Cameroon: A Stochastic Frontier Model Approach
}

\author{
Djomo, Raoul Fani*1, Ewung, Bethel ${ }^{1}$, Egbeadumah, Maryanne Odufa ${ }^{2}$ \\ ${ }^{1}$ Department of Agricultural Economics. University of Agriculture, Makurdi. Benue-State, \\ Nigeria PMB 2373, Makurdi \\ ${ }^{2}$ Department of Agricultural Economics and Extension, Federal University Wukari, \\ PMB 1020 Wukari. Taraba State, Nigeria \\ *raoulfani@gmail.com
}

\begin{abstract}
Local farmers' techniques and knowledge in rice cultivation being deficient and the aid system and research to support such farmers' activities likewise insufficient, technological progress and increase in rice production are not yet assured. Therefore, this Study was undertaken to assess cost efficiency among small scale rice farmers in the West Region of Cameroon using stochastic frontier model approach. A purposive, multistage and stratified random sampling technique was used in selecting the respondents. A total of 192 small scale rice farmers were purposively selected from four (4) out of eight divisions. Data were collected using structured questionnaires and interview schedule, administered on the respondents were analyzed using descriptive statistics and stochastic frontier cost functions. The result indicates that the coefficient of cost of labour was found positive and significantly influence cost of production in small scale rice production at 1 percent level of probability, implying that increases in cost of labour by one unit will also increase cost of production in small scale rice farming by the value of it coefficient. Similarly, the coefficients of price of fertilizer and rice output were found positive and significantly influence cost of production in small scale rice farming at 5 percent level of probability, implying that increases in price of fertilizer and rice output will also increase the cost of production in small scale rice farming by the value of their coefficients respectively. The estimated coefficients of cost inefficiency effects model indicates that rice variety, extension contact and access to credit significantly influence cost inefficiency among small scale rice farmer's in the West Region of Cameroon. The average cost efficiency among small scale rice producers was 90 percent implying that small scale producers' cost efficiency could be increased by 10 percent if the available resources are not efficiently utilized. The study recommends that Appropriate supervision and follow up should be done to ensure that payment on labour use is commensurate to work done as well as rural urban migration should be discouraged since it drives labour forces from rural to urban areas.
\end{abstract}

Keywords: Cost efficiency, Small scale, Producers, Cameroon

\section{INTRODUCTION}

In Africa, delays in economic development and high population growth have given rise to poverty and food shortages. The volume of rice imports from Asia and North America has increased annually due to the rapid rise of consumption that exceeds production (JIRCAS, 2013). Meanwhile, local farmers' techniques and knowledge in rice cultivation being deficient and the aid system and research to support such farmers' activities likewise insufficient, technological progress and increase in rice production are not yet assured (JIRCAS, 2013). The agricultural sector plays an essential role in Cameroon's economy and needs to extend its contribution to growth and combating poverty. It currently accounts for $21.7 \%$ of GDP and involves $60 \%$ of the active population (World Bank, 2013). It plays a determining role in the war on poverty and food insecurity, thanks to the self-provisioning of 2000000 agricultural households in the country, and in the supply of food products to neighborhood and urban markets. It is estimated that some $80 \%$ of the food requirements of the country's population is satisfied by domestic production (World Bank, 2013). According to Djomo (2015) existing theories assume that socio-economic condition of farmers is consistent with efficient production of farm output. However, an issue of recent research interest is a question of whether socio-economic conditions of farmers are good enough to encourage efficient production of farm output. Specifically, he argues that socio-economic condition of farmers may not be favourable 
enough to enable farmers to have maximum output from inputs use. $\mathrm{He}$ is also of the view that maturity in age is a precondition for efficient production and lack of reasonable experience on the farm reduces technical expertise. In addition, educational background also enhances productivity through the use of knowledge acquired in training. Another argument is that with the low level of fixed investment involved in small scale rice farming in the West Region of Cameroon, whether expenditures in small scale rice farming leads to efficient use of resources; or that expenditures in farm inputs may not necessarily be able to upset farm output (Djomo, 2015). It has, therefore, become imperative to undertake this study to empirically assess cost efficiency among small scale rice farmers in the West Region of Cameroon.

\section{THEORETICAL FRAMEWORK}

\subsection{Cobb-Douglas Production Function}

The theoretical basis of this study focused on Cobb-Douglas (CD) production function which shows a functional relationship between inputs and output. The Cobb-Douglas (CD) function further assumes constant returns to scale and unitary elasticity of substitution.

For two variable inputs, the function can be expressed as $\mathrm{Y}=A L^{b 1} \mathrm{~K}^{\mathrm{b} 2} \mathrm{e}$

Where $\mathrm{Y}=$ level of output, $\mathrm{L}$ and $\mathrm{K}=$ variable inputs, $\mathrm{A}=$ multiplicative constant, $\mathrm{b}^{1}$ and $\mathrm{b}^{2}$ are the coefficient of $\mathrm{L}$ and $\mathrm{K}$ and they represent the direct measure of elasticity of the respective factors of production, and $e=$ error term. The sum of $b^{1}$ and $b^{2}$ indicates the nature of returns to scale. Upton (1979); Terfa and Terwase (2011) observed that, the Cobb-Douglas production function cannot show both increasing and diminishing marginal productivity in a single response curve and as a result it does not give a technical optimum and may lead to the over estimation of the economic optimum. Despite these disadvantages researchers still find the Cobb-Douglas production function useful in analysis of survey where many variable inputs are involved and it is necessary to measure returns to scale, intensity of factors of production and overall efficiency of production. It can also provide a means of obtaining coefficients for testing hypotheses (Cobb and Douglas 1928; Erhabor, 1982; Terfa and Terwase, 2011). While commenting on the superiority of Cobb-Douglas production function over other forms of production functions, Terfa and Terwase (2011) stated that, Cobb-Douglas production function is used more than the other two because it satisfies the economic, statistical and econometric criteria of many studies than others.

\section{Methodology}

The Study Area: The study was conducted in the West Region of Cameroon which has eight divisions namely: Bamboutos, Haut-Nkam, Mifi, Menoua, Khoung-khi, Nde and Hauts-Plateaux. The West Region covers a total land area of $14000 \mathrm{sq} \mathrm{km}$ and is located in the West-Central part of Cameroon within latitudes $5^{\circ} 20^{\prime}$ and $7^{\circ}$ North and longitude $9^{\circ} 40^{\prime}$ and $11^{\circ} 10^{\prime}$ East of the equator (Yerima and Van, 2005).

Population, Sampling procedure and Data Collection: A sample of the population was taken by adopting a purposive, multistage and stratified random sampling procedure. First, four divisions were purposively selected (Bamboutos, Nde, Noun, and Menoua) based on the high concentration of rice production in those divisions. The second stage involved selection of one subdivision from each of the selected divisions namely: Tonga in Nde division, Foumbot in Noun division, Santchou in Menoua division, and Galim in Bamboutos division. In stage three one community in each of the selected subdivision was selected namely: Keneghang; Babitchoua; Baigom and Sekou. Having drawn the sampling frame of 2400 rice farmers in these communities collected from the West Regional Delegation of the Cameroon's Ministry of Agriculture and Rural Development, 8 percent of the sample frame was randomly selected in each community. Thus a total of 192 small scale rice farmers were selected for the study.

\section{Variable Specification/Model Specification}

\section{Cost Efficiency Model (Stochastic Frontier model)}

The production form of Cobb-Douglas stochastic production frontier is given as:

$\mathrm{LnC}=\mathrm{bo}+\mathrm{b}_{1} \ln \mathrm{P}_{1}+\mathrm{b}_{2} \ln \mathrm{P}_{2}+\mathrm{b}_{3} \ln \mathrm{P}_{3}+\mathrm{b}_{4} \ln \mathrm{P}_{4}+\mathrm{b}_{5} \ln \mathrm{P}_{5}+\mathrm{b}_{6} \ln \mathrm{Y}+\mathrm{V}_{\mathrm{i}}-\mathrm{U}_{\mathrm{i}}$

Where; 
$\mathrm{C}=$ the cost of production in $\mathrm{fcfa}$

$\mathrm{Y}=$ output of rice in $\mathrm{kg} / \mathrm{ha}$

$P_{1}=$ cost of labour in fcfa

$\mathrm{P}_{2}=$ cost of fertilizer in fcfa

$\mathrm{P}_{3}=$ cost of pesticides in fcfa

$\mathrm{P}_{4}=$ cost of seeds in fcfa

$\mathrm{P}_{5}=$ cost of herbicides in fcfa

$\mathrm{V}_{\mathrm{i}}=$ Random errors which are assumed to be independently and identically distributed.

Cost of production is expected to be influenced positively by input price. This suggests that an increase in price of labour, price of fertilizer, price of pesticides, price of seeds, price of herbicides and rice output would increase total cost of production of rice.

The inefficiency of production was modelled in terms of the factors that are assumed to affect the efficiency of production of the farmers. Such factors are assumed to be independently distributed such that $U_{\mathrm{i}}$ is obtained by truncation (at zero) of the normal distribution with variance $\delta^{2}$ and mean $\mathrm{u}$ where the mean is defined by

$\mathrm{U}_{\mathrm{i}}=\sigma_{0}+\sigma_{1} \mathrm{Z}_{1}+\sigma_{2} \mathrm{Z}_{2}+\sigma_{3} \mathrm{Z}_{3}+\sigma_{4} \mathrm{Z}_{4}+\sigma_{5} \mathrm{Z}_{5}+\sigma_{6} \mathrm{Z}_{6}+\sigma_{7} \mathrm{Z}_{7}$

Where;

$\mathrm{U}_{\mathrm{i}}=$ Non negative random variable associated with technical inefficiency of production.

$\sigma=$ a vector of unknown parameters to be estimated.

$\mathrm{Z}_{1}=$ age of farmers in years

$\mathrm{Z}_{2}=$ Level of Education (number of years spent in school)

$\mathrm{Z}_{3}=$ number of years of farming experience in rice production

$\mathrm{Z}_{4}=$ household size (number of member living together in a house)

$\mathrm{Z}_{5}=$ rice variety (improved variety $=1$, local variety $=0$ )

$\mathrm{Z}_{6}=$ Extension contact (number of extension contact in a year)

$\mathrm{Z}_{7}=$ Access to credit (amount in fcfa).

\section{RESUlTS AND DiscUSSION}

\subsection{Socio-Economic Characteristics of Respondents}

Table 1 and 2 indicates respectively socio-economic characteristics and mean socioeconomic characteristics of respondents in the study area which includes: sex, age, marital status, household size, educational background and annual income.

Analysis of sex of respondents indicated that majority of them (59.4 percent) were male while 40.6 percent were female. This agrees with the findings of Abu et al. (2011) who found that agricultural production is mostly carried out by males in the West Region of Cameroon. This implies that small scale rice farming is mostly carried out by the male folk.

The average age of respondents was found to be 42 years. This agrees with the findings of Dontsop et al. (2009) who found that the mean age of 40 years for cocoa farmers in Cameroon. This implies that there are agile and stronger farmers involved in rice production in the study area. Specifically, 31.8 percent were in the productive age group of 40 to 49 years; 14 percent were within the age group of 20 to 29 years; 28.6 percent were in the age group of 30 to 39 years; 16.7 percent were within the age group of 50 to 59 years and 8.9 percent were in the age group of 60 years and above. Result on marital status indicated that majority of farmers ( 75.5 percent) were married; 8.9 percent were single; 7.3 percent were divorcees and 8.3 percent were widowed/widower. Since majority of small scale rice farmers were married, there is a tendency that farmers are more stable as marriage guarantees stability in their activities which may lead to increased farm productivity from learning by constant practice. 


\section{Djomo, Raoul Fani et al.}

The average size of family household was found to be 10 persons. This is slightly above the findings of Dontsop et al. (2009) who found average size of family household of 8 persons for cocoa farmers in Cameroon. This implies that there is enough family labour for rice production in the study area. Specifically, 64.1 percent of respondents had household size of 5 to 9; 17.7 percent had household size of 10 to $14 ; 10.4$ percent had household size of 15 to 19 while 7.8 percent had household size of 20 and above. The mean educational background was found to be 8 years spent in school. This implies that majority of small scale rice farmers were literate enough to adopt new technology for their production. Specifically, 17.2 percent had no formal education; 46.9 percent had primary education; 25.5 percent had secondary education while 10.4 percent had HND.

The average annual income was found to be 534,000 FCFA. This amount may be due to relative small size of the farm cultivated by most farmers in the study area. Specifically, 17.2 percent had annual income of 100,000 to 299,000 FCFA; 24.5 percent had annual income of 300,000 to 499,000 FCFA; 22.4 percent had annual income of 500,000 to 699,000 FCFA; 16.7 percent had annual income of 700,000 to 899,000 FCFA and 19.3 percent had annual income of 900,000 FCFA and above.

Table1. Distribution of Respondents According to their Socio-Economic Characteristics

\begin{tabular}{|l|l|l|l|}
\hline S/N & Variables/Categories & Frequency & Percentage \\
\hline $\mathbf{1 -}$ & Sex & & \\
\hline & Male & 114 & 59.4 \\
\hline & Female & 78 & 40.6 \\
\hline $\mathbf{2 -}$ & Total & 192 & 100 \\
\hline & Age (years) & & \\
\hline & $20-29$ & 27 & 14.1 \\
\hline & $30-39$ & 55 & 28.6 \\
\hline & $40-49$ & 61 & 31.8 \\
\hline & $50-59$ & 32 & 16.7 \\
\hline & $\geq 60$ & 17 & 8.9 \\
\hline & Total & 192 & 100 \\
\hline $\mathbf{3 -}$ & Mean Age & 41.98 & \\
\hline & Marital Status & & \\
\hline & Married & 145 & 75.5 \\
\hline & Single & 17 & 8.9 \\
\hline & Divorced & 14 & 7.3 \\
\hline & Widowed/Widower & 16 & 8.3 \\
\hline & Total & 192 & 100 \\
\hline
\end{tabular}

Source: Field Survey, 2014

Table1. Continued

\begin{tabular}{|l|l|l|l|}
\hline S/N & Variables/Categories & Frequency & Percentage \\
\hline $\mathbf{4 -}$ & Households Size & & \\
\hline & $5-9$ & 123 & 64.1 \\
\hline & $10-14$ & 34 & 17.7 \\
\hline & $15-19$ & 20 & 10.4 \\
\hline & $\geq 20$ & 15 & 7.8 \\
\hline & Total & 192 & \\
\hline & Mean Household Size & 10 & \\
\hline 5- & Educational Background & & 17.2 \\
\hline & No formal education & 33 & 46.9 \\
\hline & Primary & 90 & 25.5 \\
\hline & Secondary & 49 & 10.4 \\
\hline & HND & 20 & 100 \\
\hline & Total & 192 & \\
\hline & Mean Education & 8 & 17.2 \\
\hline 6- & Annual Income (FCFA) & & 24.5 \\
\hline & $100,000-299,000$ & 33 & 22.4 \\
\hline & $300,000-499,000$ & 47 & 16.7 \\
\hline & $500,000-699,000$ & 43 & 19.3 \\
\hline & $700,000-899,000$ & 32 & 100 \\
\hline & $\geq 900,000$ & 37 & \\
\hline & Total & 192 & \\
\hline & Mean Annual Income & 534000 & \\
\hline
\end{tabular}

Source: Field Survey, 2014 
Assessing Cost Efficiency among Small Scale Rice Producers in the West Region of Cameroon: A Stochastic Frontier Model Approach

Table2. Summary Statistics of Socio-Economic Characteristics of Small Scale Rice Farmers in the West Region of Cameroon

\begin{tabular}{|l|l|l|l|l|}
\hline Statistics & Age & Household Size & Educational Background & Annual Income (fcfa) \\
\hline Mean & 41.98 & 10 & 8 & 534,000 \\
\hline Median & 42 & 9 & 6 & 450,000 \\
\hline Mode & 39 & 8 & 6 & 400,000 \\
\hline $\begin{array}{l}\text { Standard } \\
\text { deviation }\end{array}$ & 10.86 & 4.90 & 4.84 & 378,000 \\
\hline Variance & 118.04 & 24.08 & 23.49 & 1.43884 \\
\hline Minimum & 22 & 5 & 0 & 90,000 \\
\hline Maximum & 65 & 32 & 15 & $3,500,000$ \\
\hline
\end{tabular}

Source: Field Survey, 2014

\subsection{Maximum Likelihood Estimate of Cost Function of Small Scale Rice Farmers in the West Region of Cameroon}

Table 3 summarized the estimate from the stochastic cost function among small scale rice farmers in the West Region of Cameroon. As indicated in table 3, the estimated sigma square $\left(\sigma^{2}\right)$ is significant at 1 percent level of probability among small scale rice farmers indicating goodness of fit and correctness of the specified distribution assumption of the composite error terms. The estimated gamma $(\Gamma)$ is significant at 1 percent implying that 6 percent of the variability in cost of production among small scale rice farmers is due to cost inefficiency.

The result indicates that cost of labour, price of fertilizer and rice output were the factors that significantly affect the cost of production among small scale rice farmers in the West Region of Cameroon. Specifically, the coefficient of cost of labour was found positive and significantly influence cost of production in small scale rice production at 1 percent level of probability, implying that increases in cost of labour by one unit will also increase cost of production in small scale rice farming by the value of it coefficient. Similarly, the coefficients of price of fertilizer and rice output were found positive and significantly influence cost of production in small scale rice farming at 5 percent level of probability, implying that increases in price of fertilizer and rice output will also increase the cost of production in small scale rice farming by the value of their coefficients respectively. However, the estimated coefficients for price of pesticides cost of seeds and price of herbicides were not significant. This implies that these variables have no influence on the cost of production in small scale rice farming.

The return to scale is 0.91 with respect to cost of labour, price of fertilizer and output of rice, which is positive. Technically small scale rice farmers are in stage II of their production cycle as the cost of production is increasing at decreasing rate relative to price of inputs and quantity of rice output. This also implies that 1 percent increase in price of all inputs and quantity of rice output lead to 0.91 percent increases in cost of production in small scale rice farming in the West Region of Cameroon.

The estimated coefficients of cost inefficiency effects model indicates that rice variety, extension contact and access to credit significantly influence cost inefficiency among small scale rice farmer's in the West Region of Cameroon. However, age, education, experience, household size have no influence on cost inefficiency among smallholder rice farmers in the study area. The coefficients of rice variety and access to credit were negative and significant at 1 percent level of probability. Similarly, the coefficient of extension visit was negative and significant at 5 percent level of probability. The implication is that cost inefficiency effects among small scale rice producers in the West Region of Cameroon declined with increase in rice variety; access to credit and extension contacts. In order words, improved rice variety; access to credit and farmer's contact with extension agents in the West Region of Cameroon has positive effects on cost efficiency among small scale rice producers. It is therefore important for achieving effective minimization of cost of production in small scale rice farming in the West Region of Cameroon.

\subsection{Cost Efficiency Estimates of Small Scale Rice Producers in the West Region of Cameroon}

The cost efficiency estimates summarized in table 4 indicates that small scale rice producers in the West Region of Cameroon had cost efficiency varying from 67 to 99 percent with the mean of 90 percent. This implies that cost efficiency in small scale rice production in the West Region of 


\section{Djomo, Raoul Fani et al.}

Cameroon could be increased by 10 percent through inefficient use of available resources given the current state of technology and this could be achieved through the use of improved rice variety; access to credit and better extension contacts. Specifically, 3.64 percent of small scale rice farmers had cost efficiency of 0.65 to $0.70 ; 4.16$ percent of small scale rice farmers had cost efficiency of 0.71 to 0.76 ; 9.89 percent had cost efficiency of 0.77 to $0.82 ; 10.93$ percent had cost efficiency of 0.83 to 0.88 ; 19.27 percent had cost efficiency of 0.89 to 0.94 and finally, 52.08 percent had cost efficiency of 0.95 to 1 .

Table3. Maximum Likelihood Estimate of Cost Function of Small Scale Rice Farmers in the West Region of Cameroon

\begin{tabular}{|l|l|l|}
\hline Variables & Coefficients & Estimated values of Coefficients \\
\hline Constant & $\mathrm{b}_{0}$ & $7.28(4.89)^{* *}$ \\
\hline Cost of Labour & $\mathrm{b}_{1}$ & $0.35(4.02)^{* *}$ \\
\hline Price of Fertilizer & $\mathrm{b}_{2}$ & $0.36(1.96)^{*}$ \\
\hline Price of Pesticides & $\mathrm{b}_{3}$ & $-0.04(-0.36)$ \\
\hline Price of Seeds & $\mathrm{b}_{4}$ & $-0.09(0.35)$ \\
\hline Price of Herbicides & $\mathrm{b}_{5}$ & $0.05(0.20)$ \\
\hline Output of rice & $\mathrm{b}_{6}$ & $0.2(2.26)^{*}$ \\
\hline Inefficiency parameters & & \\
\hline Constant & $\sigma_{0}$ & $0.85(2.35)$ \\
\hline Age & $\sigma_{1}$ & $0.17(0.7)$ \\
\hline Education & $\sigma_{2}$ & $0.03(0.41)$ \\
\hline Experience & $\sigma_{3}$ & $0.06(0.82)$ \\
\hline Household Size & $\sigma_{4}$ & $0.02(0.32)$ \\
\hline Rice Variety & $\sigma_{5}$ & $-0.15(-2.77)^{* *}$ \\
\hline Extension Contact & $\sigma_{6}$ & $-0.01(-1.98)^{*}$ \\
\hline Access to Credit & $\sigma_{7}$ & $-0.06(-3.34)^{* *}$ \\
\hline Sigma Square & $\sigma^{2}$ & $-0.06(2.59)^{* *}$ \\
\hline Gamma & $\Gamma$ & $0.06(9.6)^{* *}$ \\
\hline Log likelihood Function & & -9.8 \\
\hline LR test & LR & $18^{*}$ \\
\hline
\end{tabular}

Source: Field Survey, $2014 * *$ and $*$ are significant at 1 and $5 \%$. Figures in bracket are $t$ values

Table4. Distribution of Respondents by Cost Efficiency Estimates among Small Scale Rice Producers in the West Region of Cameroon

\begin{tabular}{|l|l|l|}
\hline Cost Efficiency & Frequency & Percentage (\%) \\
\hline $0.65-0.70$ & 7 & 3.64 \\
\hline $0.71-0.76$ & 8 & 4.16 \\
\hline $0.77-0.82$ & 19 & 9.89 \\
\hline $0.83-0.88$ & 21 & 10.93 \\
\hline $0.89-0.94$ & 37 & 19.27 \\
\hline $0.95-1$ & 100 & 52.08 \\
\hline Total & 192 & 100 \\
\hline Minimum & 0.67 & \\
\hline Maximum & 0.99 & \\
\hline Mean & 0.90 & \\
\hline
\end{tabular}

Field Survey, 2014

\section{CONCLUSION AND RECOMMENDATIONS}

This Study was undertaken to assess cost efficiency among small scale rice producers in the West Region of Cameroon using stochastic frontier model approach. The results revealed that cost of labour, price of fertilizer and rice output were the factors that significantly affect the cost of production among small scale rice producers in the West Region of Cameroon. The results further revealed that rice variety, extension contact and access to credit significantly influence cost inefficiency among small scale rice producers in the West Region of Cameroon. The mean cost efficiency for small scale rice producers is 90 percent. This suggests that cost efficiency could be increased by 10 percent given the current level of technology if the available resources are inefficiently utilized. It is therefore recommended that: 
- Appropriate supervision and follow up should be done to ensure that payment on labour use is commensurate to work done as well as rural urban migration should be discouraged since it drives labour forces from rural to urban areas.

- Subsidies on fertilizer, seeds, pesticides and herbicides should be given to farmers in order to reduce their cost of production.

- Policy makers should put more emphasis on improved seeds variety, extension contact and access to credit since they can reduce cost inefficiency significantly.

\section{REFERENCES}

Abu, G.A., Djomo, C.R.F., and Okpachu, S.A. (2011). Evaluating the Constraints and Opportunities of Maize Production in the West Region of Cameroon for Sustainable Development. Journal of Sustainable Development in Africa. 4(13):189-196. Clarion University of Pennsylvania, Clarion, Pennsylvania

Cobb, C.W. and Douglas, P.H. (1928) “A Theory of production" American economic review supplement 18: $139-165$.

Djomo, C.R.F. (2015). Analysis of Technical Efficiency and Profitability in Small Scale rice Production in the West Region of Cameroon. M.Sc. Thesis submitted to the Department of Agricultural Economics. University of Agriculture, Makurdi-Benue State, Nigeria

Dontsop, P.M., Rhaji, A.Y., and Adelakun, O.J. (2009). Determinants of technical Efficiency of cocoa farmers in Cameroon:The case study of Central province. Journal of Economics and Social Studies, Vol (6):32-53.

Erhobor, P.O. (1982) "Efficiency of Resources use under small Scale Irrigation Technology in Nigeria" Purdue University; Water Resources Research Center West Lafayettse, Indiana, USA.Technical Report No 148 pp 1-114.

Terfa, D.A. and Terwase, S. (2011). Efficiency of Resource Use in Rice Farming Enterprise in Kwande Local Government Area of Benue State, Nigeria. International Journal of Humanities and Social Science Vol. 1 No. 3; March 201.pp. 4-6.

Upton, M. (1979). Farm Management in Africa: The Principles of Production and Planning. Oxford University, Oxford 260pp.

Japan International Research Center for Agricultural Sciences (JIRCAS). (2013). Tropical Agriculture Research Front. Pp. 10-11.

World bank (2013). Basic agricultural public expenditure diagnostic review (2003-12) republic of Cameroon. Strengthening National Comprehensive agricultural public expenditure in SubSaharan Africa. Pp1-131

\section{AUTHORS' BIOGRAPHY}

Djomo, Raoul Fani, is a Phd at the Department of Agricultural Economics, Federal University of Agriculture, Makurdi-Benue State and Lecturer at the Federal University Wukari, Taraba-State, Nigeria

Ewung, Bethel, is a $\mathrm{PhD}$ at the department of agricultural economics, Federal university of agriculture, Makurdi-Benue State and lecturer at the federal university wukari, Taraba-State, Nigeria

Egbeadumah, Maryanne Odufa, is a $\mathrm{PhD}$ at the department of agricultural economics, Federal university of agriculture, Makurdi-Benue State. And lecturer at the Department of agricultural economics and extension, federal university wukari, Taraba-State, Nigeria 